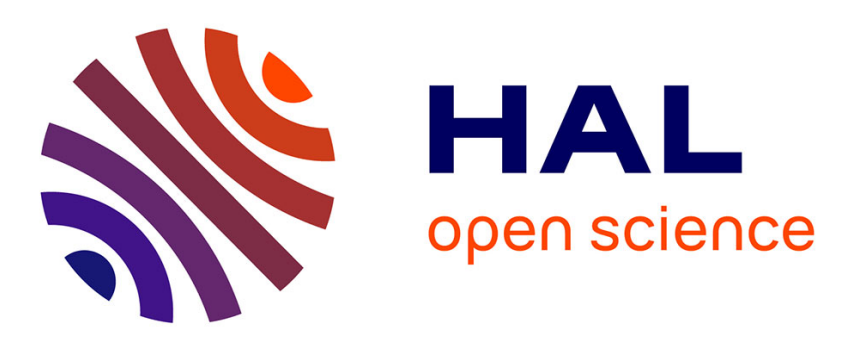

\title{
An Innovative Methodology to Design LCM Mold for Aeronautic and Automotive Industries
}

\author{
A. Ouezgan, S. Adima, A. Maziri, E. Mallil, J. Echaabi
}

\section{To cite this version:}

A. Ouezgan, S. Adima, A. Maziri, E. Mallil, J. Echaabi. An Innovative Methodology to Design LCM Mold for Aeronautic and Automotive Industries. 19th International TRIZ Future Conference (TFC),

Oct 2019, Marrakesh, Morocco. pp.472-485, 10.1007/978-3-030-32497-1_37 . hal-02905535

\section{HAL Id: hal-02905535 \\ https://hal.inria.fr/hal-02905535}

Submitted on 23 Jul 2020

HAL is a multi-disciplinary open access archive for the deposit and dissemination of scientific research documents, whether they are published or not. The documents may come from teaching and research institutions in France or abroad, or from public or private research centers.
L'archive ouverte pluridisciplinaire HAL, est destinée au dépôt et à la diffusion de documents scientifiques de niveau recherche, publiés ou non, émanant des établissements d'enseignement et de recherche français ou étrangers, des laboratoires publics ou privés.

\section{(c)(1)}

Distributed under a Creative Commons Attribution| 4.0 International License 


\title{
AN INNOVATIVE METHODOLOGY TO DESIGN LCM MOLD FOR AERONAUTIC AND AUTOMOTIVE INDUSTRIES
}

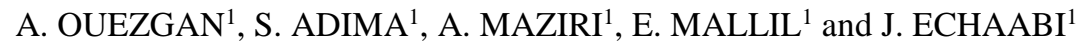 \\ 1 Équipe de Recherche Appliquée sur les Polymères, Département de Génie Mécanique, \\ ENSEM, Université Hassan II de Casablanca, BP 8118, Oasis, Casablanca, Maroc. \\ Ahmedouezgan@gmail.com
}

\begin{abstract}
The liquid composite molding family (LCM) includes several processes like RTM ("Resin transfer molding") and VARI ("Vacuum assisted resin infusion"), to satisfy the requirements of each industry. The objectives of recent years in the automotive and aerospace industries tend towards better control of production costs by using of new materials, shorter manufacturing cycles, a higher level of performance and safety and better environmental respect. In the automotive sector, a short cycle time and a lower cost equipment are the most criteria to determine a suitable process, while the quality of the part is the primary parameter for aeronautical process selection. The main objective of this paper is to propose and discuss a new design of LCM mold, allowing at the same time to facilitate the manufacturing process, in particular to reduce the cycle time and to respect the material's health by obtaining a part with minimum defects. This innovation is achieved by using the TRIZ theory (theory of inventive problem solving), in order to eliminate the contradictions that exist between the requirements of the two sectors.
\end{abstract}

Keywords: LCM, TRIZ, Automotive, Aeronautic.

\section{Introduction}

Liquid composite molding (LCM) refers to composite manufacturing processes in which a fibrous preform material is placed into a mold cavity and a thermosetting resin with a relatively low viscosity is impregnated the preform until all empty spaces between the fibers are filled, and finally cured to create a polymeric composite structure [1]. Due to its capacity to significantly reduce the release of volatile organic compounds (VOCs) to the atmosphere, the LCM manufacturing processes has gained attention compared with current methods of open molding processes. They have also been created to overcome the intrinsic weaknesses of autoclave draping processes such as: their high tooling cost and their long cycle time. The LCM processes are distinguishable from each other by the nature of the mold used and the manner of the filling phase. The LCM mold is divided in two parts, the lower part of the mold is always rigid but the upper part is possibly be rigid, like in RTM, CRTM and flexible injection, semi-flexible (RTM-light) or flexible such as in VARTM, VARI and LRI, while the resin can be introduced using a combination of a positive injection pressure 
(use of an injection machine), vacuum infusion (use of a vacuum pump), and possibly assisted by the compaction force.

The Resin transfer molding (RTM) is one of the most recognized LCM processes, it was adopted for composite manufacturing in the mid-1980s. RTM manufacturing includes several steps. It begins by placing a dry fibrous reinforcement inside a rigid mold, closing the mold, injecting a liquid resin, curing the resin and finally demolding the part. Due to its several advantages [2], RTM has received the most industrial attention $[3,4]$. The most important objective of this process is to reduce the time it takes to fill the mold with resin. This will increase the production rate and reduce manufacturing costs and also ensure that the fabric preform is completely saturated before the resin starts to gel [5]. The conventional RTM processes usually have limitations in fabrication large parts due to the cost investments, pressure equipment, and the process time, that dramatically increasing proportional to the surface area of composite structures [6].

The vacuum assisted resin transfer molding (VARTM) process was introduced to overcome these challenges. In this process a fibrous preform is placed into a mold cavity, and covers by a flexible polymer film, then a sealant tape is used to adhere it to the mold in order to avoid air-resin leakage. A vacuum pump is used to evacuate the air from the cavity, which leads to compact the preform. The inlet gate is opened and resin impregnates the preform under atmospheric pressure. The main disadvantages of the VARTM process are: First, the pressure gradient is limited to one atmospheric pressure so the mold filling is very slow and the filling time increasing proportional to the part's dimensions [1], along with the low permeability of typical fiber layers often leads the resin to not completely fill the mold cavity before the resin begins to gel. To solve these issues many authors and multinational companies have developed the new variants of VARTM, like as SCRIMP [7], FFC method [8] and VIPR [9]. However, as all these variants use only a single rigid side mold, the fabricated part has low dimensional tolerances due to the non-uniformity of part thickness, and low fiber volume fraction. These processes have still limited to non-aerospace applications.

The CRTM, compression resin transfer molding, also known as injection-compression molding (I/CM) [5, 6], is another variant of RTM. In this process the upper part of the mold is rigid and moveable in order to increase the fiber volume fraction and to improve the surface quality of the part. Moreover it minimizes the entrapment of air pockets, by applying a compression force that squeeze and displace all air and volatiles bubbles out through the vent gate. Also the CRTM reduce the injection pressure, fill time and give answer to limitation of in-plane impregnation velocity as compared to RTM. The Steps for fabricating the composite part by CRTM are described in details in [7]. Although its advantages, the CRTM needs a high force to displace the moveable upper mold and to better compress the preform, this lead to increase cost equipment and to deform mold walls which influence the part quality.

Chang proposed another variant of VARTM called Vacuum assisted compression resin transfer molding. This process has been developed to reduce the mold filling time, injection pressure and cleaning mold time compared with resin transfer molding. The vacuum-assisted compression resin transfer molding utilizes a flexible membrane 
placed between the upper mold and the mold cavity compared with RTM. Before the injection phase takes place, the air is evacuated from the upper mold by using a vacuum pump which forces the membrane to lift up and to relax the fibers. Thus the resin can be easily entered into the cavity. Once enough amount of resin is introduced, a compression pressure is applied on the film that compacts the fibers and conducts the resin through the preform. Some shortcomings are inevitable including the edge effect and excess of injected resin. More resin leads to a longer injection and compression phase and more wastes [10].

The main objective of this paper is to propose and discuss a new design of LCM mold allowing at the same time to satisfy the requirements of aeronautic and automotive industries. This innovation is achieved by using the TRIZ theory (theory of inventive problem solving), in order to solve the contradictions existed between these sectors.

\section{TRIZ theory}

TRIZ is the Russian acronym for the inventive problem solving theory, created and developed by the Russian engineer G. Altshuller in 1946. Over the past years, TRIZ has used in different sectors, including electrical Engineering [11], chemical engineering [12], automotive sector[13], mechanical field [14], and environmental area [15]. Due to these large scope of applications, nowadays TRIZ has become as one of the most powerful, popular innovative method. Figure 1 illustrates TRIZ theory methodology.

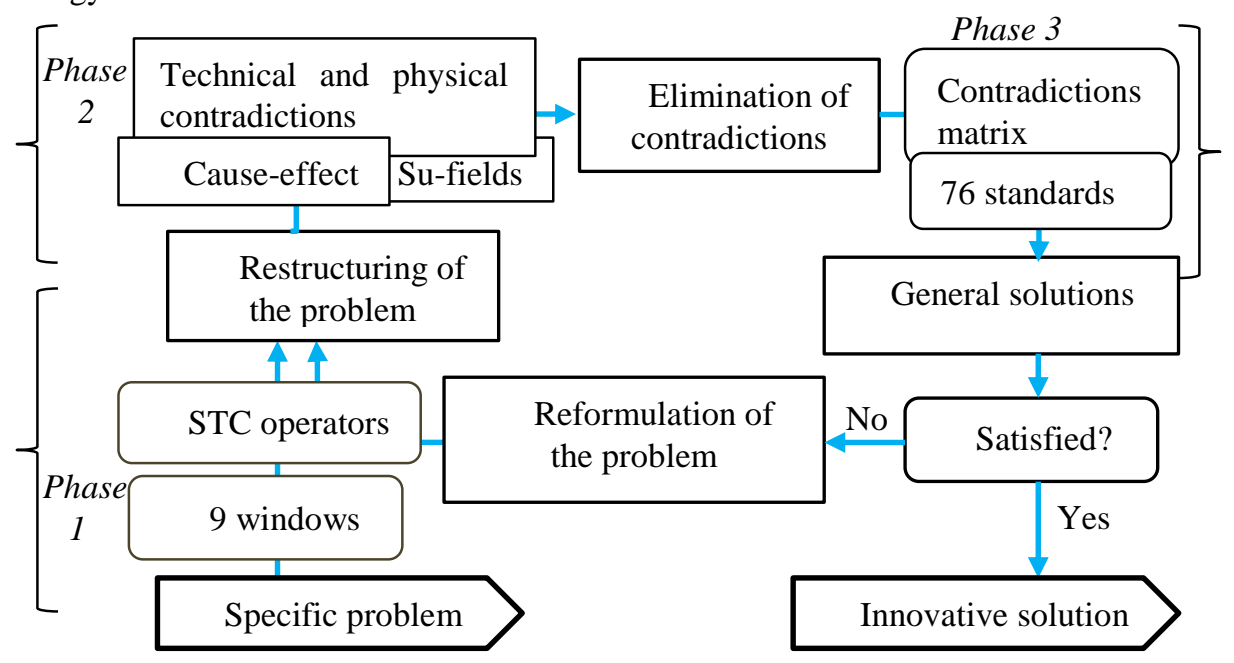

Fig. 1. TRIZ theory methodology.

This method is based on three main phases [16-19]:

Phase 1: Description and understanding of the specific problem

This phase is essential to better understand and formulate correctly the problem, it's applicable in four steps: 
- The description of the project.

- The analysis of the system.

- The identification of the problems.

- Ideal final result formulation.

During this phase, it's recommended to use some rules and apply the TRIZ tools such as, miniature men's method, STC operators and the nine windows tool that allow us to avoid psychological inertia.

Phase 2: Formulation and modeling of the problem

It is used to find the contradictions between the parameters of the system by using the following tools.

- Cause-effect analysis.

- Technical and physical contradictions.

- Substances-Field Models (Su-Field analysis).

- Laws of engineering systems evolutions.

Phase 3: generation of solutions

It allows to solve the previous contradictions and to generate models of solutions by using the following tools:

- Contradictions matrix.

- Separation principles.

- 76 standards.

\section{Description and understanding of the specific problem}

\subsection{External functional analysis}

This tool is used to understand why the system exist, in addition to identify the principal functions (PF) and the constraints functions $(\mathrm{CF})$ related to the system. Figure 2 shows external functional analysis of LCM processes [20].

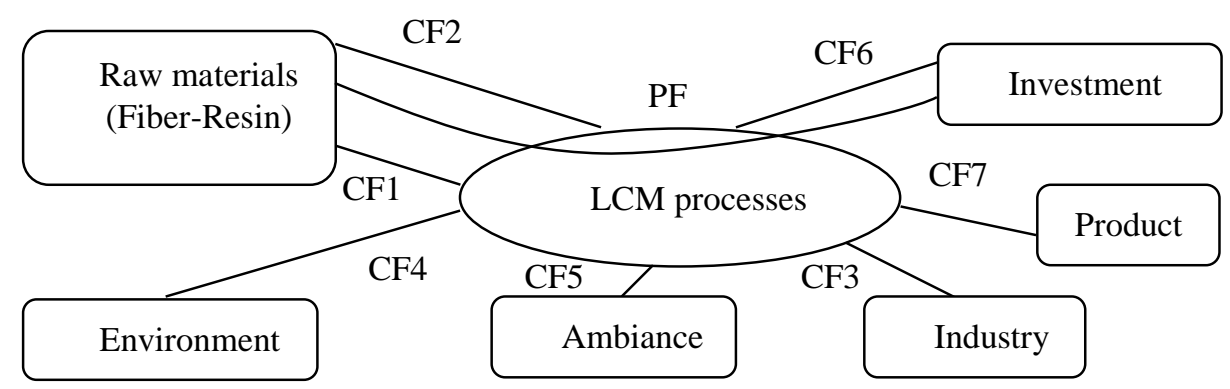

Fig. 2. External functional analysis.

PF: Transform the raw materials into the desired product.

CF1: Inject and quickly fill the mold without any resin leakage.

CF2: Compact uniformly the fibrous reinforcement. 
CF3: Be profitable.

CF4: Resist to the aggressive environment (noise, dust, humidity and other industrial environments).

CF5: Do not pollute the environment (mechanical noise, Chemical emissions (styrene)).

CF6: Do not require a huge investment.

CF7: Give a good surface finish and close dimensional tolerances.

\subsection{Structural decomposition}

This tool is used to identify all system and subsystems components and their functions. Figure 3 presents the structural decomposition of LCM mold.

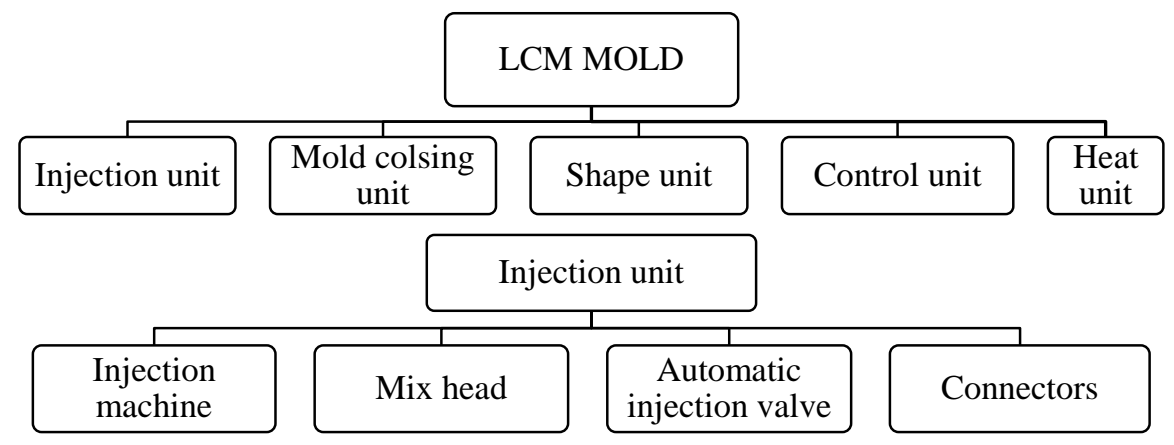

Fig. 3. Structural decomposition of LCM mold.

Mold closing unit: Allows to close the mold and ensure a better seal between the lower and the upper half mold, as well as to obtain a uniform fiber compaction.

Shape unit: Includes two sides of the mold, carved inside them the part shape, the inlet gates, the vent gates and the sealing tapes.

Control unit: Includes all tools used to measure and control process variables, as well as give information about system evolution.

Heat unit: Allows to control the temperature of the resin and the mold in order to govern the resin impregnation velocity during injection phase and polymerization reaction during consolidation phase.

Injection machine: Permits to store and to transfer the resin and additives from their separate tanks to the mold cavity.

Mix head: Allows to mix the resin with fillers and additives, and gives to operators a tool to control and change the velocity of polymerization reaction in the mold.

Automatic injection valves: Are mounted at the injection gates to connect the metering line. They protect against backflow and generate a defined back pressure.

\subsection{Ideal Final Result expression}

In the automotive sector, a short cycle time and a lower cost equipment are the most criteria to determine a suitable process, while the quality of the part is the primary parameter for aeronautical process selection. These factors depend on the part dimen- 
sion, fill time, cure time, surface quality, dimensional tolerances and fiber volume fraction. All these dictated conditions include the conflict links and contradictions that can't be solved by using only the compromises thinking. The use of TRIZ theory permit to achieve this goal by proposing a new process capable to satisfy the requirements of aeronautic and automotive industries.

\section{Cause-effect analysis}

The cause-effect diagram is a TRIZ tool, used to identify the useful and harmful resources of the LCM manufacturing processes and its environment, as well as to find the contradictions and conflict links between all parameters mentioned above. Figure 4 illustrates the process of generating creative solutions by using cause-effect analysis.

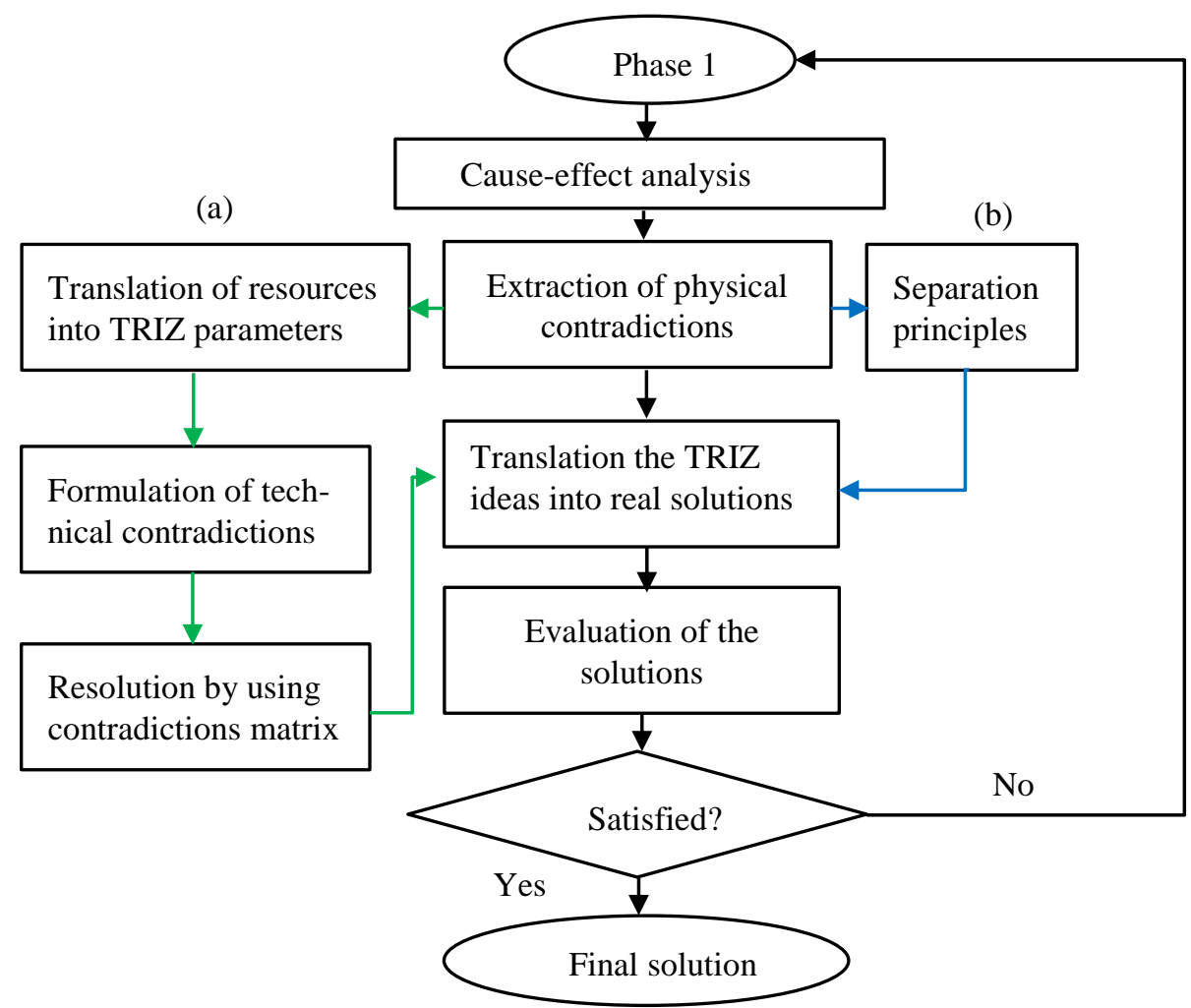

Fig. 4. Cause-effect analysis process (a) by using contradictions matrix (b) by using separation principles

In this article, we are interested to utilize cause-effect analysis methodology by using contradictions matrix (path a). The cause effect diagram of LCM manufacturing processes is presented in figure 5. 


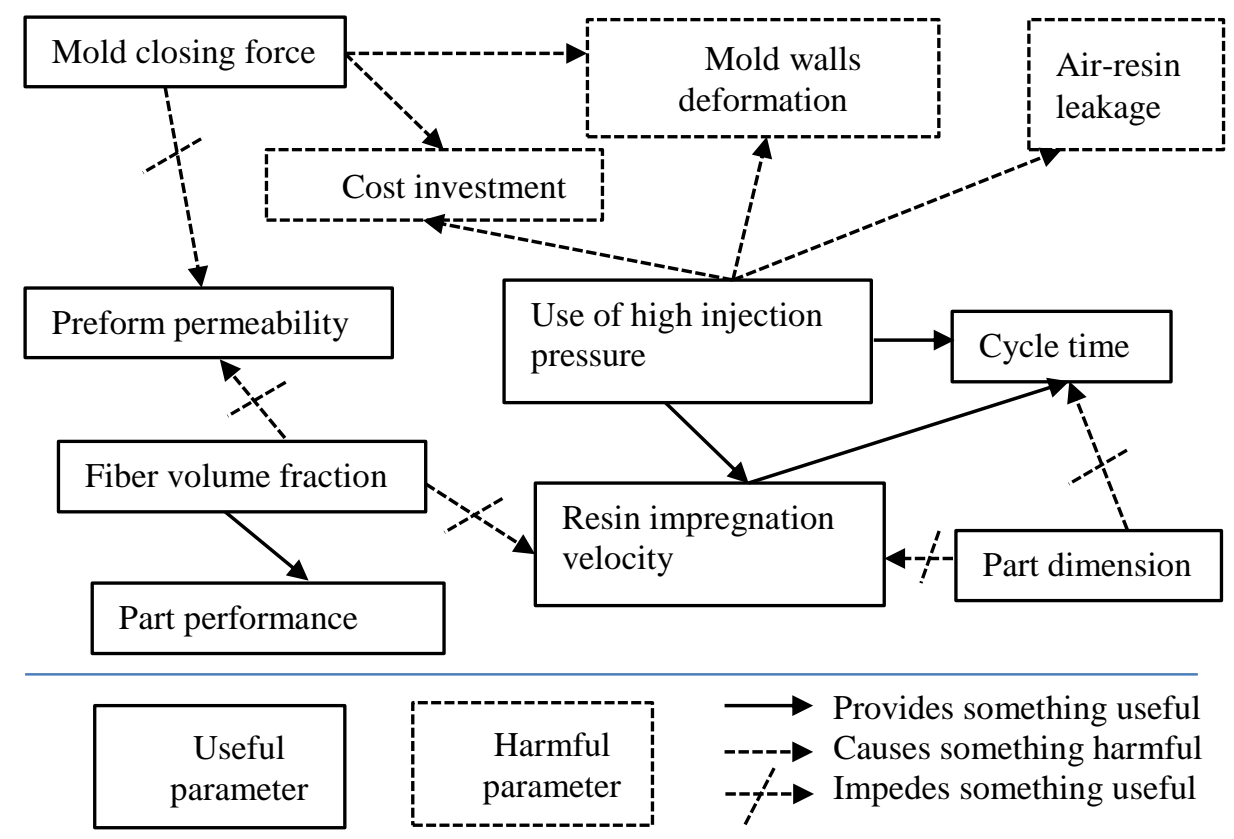

Fig. 5. Cause-effect analysis of LCM manufacturing processes.

\subsection{Extraction of physical contradictions}

A physical contradiction (PC) is a situation in which an engineering system require contradictory values from the same parameter [21]. In our problem the physical contradictions are presented as follows:

PC1: The mold closing force should be high (should exist) to increase the fiber volume fraction and avoid air-resin leakage, and should not be high (should not exist) to avoid mold walls deformation and huge cost investment as well as because it impedes the preform permeability.

PC2: The useful factor (fiber volume fraction) should be high (should exist) to manufacture performance parts, and should not be high (should not exist) because it thwarts another useful factors (resin impregnation velocity) and (preform permeability).

PC3: The manufacture of large parts should exist to satisfy the requirements of industry and should not exist because it impedes the resin impregnation velocity and short cycle time.

PC4: The injection pressure should be high to reduce cycle time and increase the resin impregnation speed and should not be high in order to avoid mold walls deformation, air-resin leakage and huge cost investment.

\subsection{Translation of resources into TRIZ parameters}

In this step we transform the specific expressions of LCM manufacturing processes to 
typical parameters in the engineering contradiction using the 39 universal technical parameters from TRIZ matrix.

Table 1. Translation of LCM parameters into TRIZ parameters.

\begin{tabular}{ll}
\hline Specific expression & TRIZ parameters \\
\hline Mold closing force & Force \\
Mold deformation walls & Stability of object \\
Air-resin leakage & Waste of substance \\
Cost investment & Productivity \\
Preform permeability & Convenience of use \\
Use of high injection pressure & Tension/pressure \\
Cycle time & Waste of time \\
Fiber volume fraction & Amount of substance \\
Resin impregnation velocity & Speed \\
Part dimension & Manufacturability \\
Part performance & Reliability \\
\hline
\end{tabular}

\subsection{Formulation of technical contradictions}

A technical contradiction (TC) is a situation in which the improvement of a function or the elimination of a harmful effect leads to the unacceptable deterioration of another function [22]. A technical contradiction is formulated in the following form:

The improvement of (specific expression / TRIZ parameter) degrades (specific expression / TRIZ parameter).

From the physical contradiction 1 (PC1), we have obtained the following technical contradictions (TC):

TC1: The improvement of (Mold closing force / Force) degrades (Mold deformation walls / Stability of object).

TC2: The improvement of (Mold closing force / Force) degrades (Cost investment / Productivity).

TC3: The improvement of (Mold closing force / Force) degrades (Preform permeability / Convenience of use).

TC4: The improvement of (Fiber volume fraction / Amount of substance) degrades (Mold deformation walls / Stability of object).

TC5: The improvement of (Fiber volume fraction / Amount of substance) degrades (Cost investment / Productivity).

TC6: The improvement of (Fiber volume fraction / Amount of substance) degrades (Preform permeability / Convenience of use).

\subsection{Resolution by using the contradiction matrix}

The contradiction matrix is the most recognized TRIZ tool because of its ease of use. In this matrix, the lines correspond to the parameters to be improved, while the col- 
umns include the parameters which are degraded. At the intersection, the matrix gives one to four inventive principles for guiding the user to solve this contradiction [23].

Table 2. The contradiction matrix.

\begin{tabular}{|c|c|c|c|c|c|c|c|c|c|c|c|}
\hline parameter & $\begin{array}{l}0 \\
\stackrel{0}{0} \\
\text { I. }\end{array}$ & 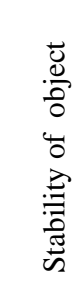 & 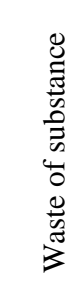 & 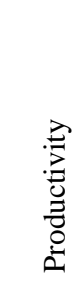 & 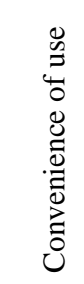 & 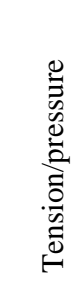 & 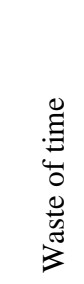 & 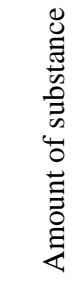 & $\begin{array}{l}\vec{\otimes} \\
\text { ڤ̆ } \\
\text { के }\end{array}$ & 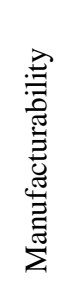 & 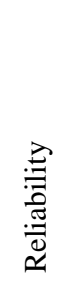 \\
\hline Force & & $\begin{array}{l}35,10 \\
, 21 \\
\end{array}$ & $\begin{array}{l}8,35 \\
40,5 \\
\end{array}$ & $\begin{array}{l}3,28 \\
35,37\end{array}$ & $\begin{array}{l}1,28 \\
3,25\end{array}$ & $\begin{array}{l}18,21 \\
4 \\
\end{array}$ & $\begin{array}{l}10,37 \\
36 \\
\end{array}$ & $\begin{array}{l}14,29 \\
18,36 \\
\end{array}$ & $\begin{array}{l}13,28 \\
15,12 \\
\end{array}$ & $\begin{array}{l}15,37 \\
18,1 \\
\end{array}$ & $\begin{array}{l}3,35 \\
13,21 \\
\end{array}$ \\
\hline $\begin{array}{l}\text { Stability of } \\
\text { object }\end{array}$ & $\begin{array}{l}10,35 \\
21,16 \\
\end{array}$ & & $\begin{array}{l}2,14, \\
30,40\end{array}$ & $\begin{array}{l}23,35 \\
40,3 \\
\end{array}$ & $\begin{array}{l}32,35 \\
30 \\
\end{array}$ & $\begin{array}{l}2,35, \\
40\end{array}$ & 35,27 & $\begin{array}{l}15,32 \\
35 \\
\end{array}$ & $\begin{array}{l}33,15 \\
28,18 \\
\end{array}$ & 35,19 & 0 \\
\hline $\begin{array}{l}\text { Waste of } \\
\text { substance }\end{array}$ & $\begin{array}{l}14,15 \\
18,40 \\
\end{array}$ & $\begin{array}{l}2,14, \\
30,40\end{array}$ & & $\begin{array}{l}28,35 \\
10,23 \\
\end{array}$ & $\begin{array}{l}32,28 \\
2,24 \\
\end{array}$ & $\begin{array}{l}3,36, \\
37,10\end{array}$ & $\begin{array}{l}15,18 \\
35,10 \\
\end{array}$ & $\begin{array}{l}6,3 \\
10,24\end{array}$ & $\begin{array}{l}10,13 \\
28,38 \\
\end{array}$ & $\begin{array}{l}15,34 \\
33 \\
\end{array}$ & $\begin{array}{l}10,29 \\
39,35 \\
\end{array}$ \\
\hline Productivity & $\begin{array}{l}10,37 \\
14 \\
\end{array}$ & $\begin{array}{l}35,3, \\
22,39 \\
\end{array}$ & $\begin{array}{l}28,10 \\
35,23 \\
\end{array}$ & & $\begin{array}{l}1,28, \\
7,10\end{array}$ & $\begin{array}{l}10,37 \\
14 \\
\end{array}$ & 0 & 35,38 & 0 & $\begin{array}{l}35,28 \\
2,24 \\
\end{array}$ & $\begin{array}{l}1,35 \\
10,38 \\
\end{array}$ \\
\hline $\begin{array}{l}\text { Convenience } \\
\text { of use }\end{array}$ & $\begin{array}{l}28,13 \\
35\end{array}$ & $\begin{array}{l}32,35 \\
30\end{array}$ & $\begin{array}{l}28,32 \\
2,24\end{array}$ & $\begin{array}{l}15,1, \\
28\end{array}$ & & $\begin{array}{l}2,32, \\
12\end{array}$ & $\begin{array}{l}4,28 \\
10,34\end{array}$ & $\begin{array}{l}12, \\
35\end{array}$ & $\begin{array}{l}18,13 \\
34\end{array}$ & $\begin{array}{l}2,5 \\
12\end{array}$ & $\begin{array}{l}17,27 \\
8,40 \\
\end{array}$ \\
\hline $\begin{array}{l}\text { Tension } \\
\text { /pressure }\end{array}$ & $\begin{array}{l}36,35 \\
21\end{array}$ & $\begin{array}{l}35,33 \\
2,40\end{array}$ & $\begin{array}{l}10,36 \\
3,37\end{array}$ & $\begin{array}{l}10,14 \\
35,37\end{array}$ & 11 & & $\begin{array}{l}37,36 \\
4\end{array}$ & $\begin{array}{l}10,14 \\
36\end{array}$ & $\begin{array}{l}6,35, \\
36\end{array}$ & $\begin{array}{l}1,35 \\
16\end{array}$ & $\begin{array}{l}10,13 \\
19,35\end{array}$ \\
\hline $\begin{array}{l}\text { Waste of } \\
\text { time }\end{array}$ & $\begin{array}{l}10,37 \\
36,5 \\
\end{array}$ & $\begin{array}{l}35,3, \\
22,5\end{array}$ & $\begin{array}{l}35,18 \\
10,39 \\
\end{array}$ & 0 & $\begin{array}{l}4,28, \\
10,34\end{array}$ & $\begin{array}{l}37, \\
36,4\end{array}$ & & $\begin{array}{l}35,38 \\
18,16 \\
\end{array}$ & 0 & $\begin{array}{l}35,28 \\
34,4 \\
\end{array}$ & $\begin{array}{l}10,30 \\
4\end{array}$ \\
\hline $\begin{array}{l}\text { Amount of } \\
\text { substance }\end{array}$ & $\begin{array}{l}35,14 \\
3\end{array}$ & $\begin{array}{l}15,2, \\
17,40\end{array}$ & $\begin{array}{l}6,3 \\
10,24\end{array}$ & $\begin{array}{l}13,29 \\
3,27\end{array}$ & $\begin{array}{l}35,29 \\
25,10\end{array}$ & $\begin{array}{l}10,36 \\
14,3 \\
\end{array}$ & $\begin{array}{l}35,38 \\
18,16\end{array}$ & & $\begin{array}{l}35,29 \\
34,28\end{array}$ & $\begin{array}{l}29,1, \\
35,27\end{array}$ & $\begin{array}{l}18,3 \\
28,40\end{array}$ \\
\hline Speed & $\begin{array}{l}13,28 \\
15,19 \\
\end{array}$ & $\begin{array}{l}28,33 \\
1,18 \\
\end{array}$ & $\begin{array}{l}10,13 \\
28,38 \\
\end{array}$ & 0 & $\begin{array}{l}32,28 \\
13,12 \\
\end{array}$ & $\begin{array}{l}6,18, \\
38,40 \\
\end{array}$ & 0 & $\begin{array}{l}10,19 \\
29,38 \\
\end{array}$ & & $\begin{array}{l}35,13 \\
8,1 \\
\end{array}$ & $\begin{array}{l}11,35 \\
27,28 \\
\end{array}$ \\
\hline $\begin{array}{l}\text { Manufactur- } \\
\text { ability }\end{array}$ & 35,12 & $\begin{array}{l}11,13 \\
1\end{array}$ & $\begin{array}{l}15,34 \\
33\end{array}$ & $\begin{array}{l}35,1, \\
10,28\end{array}$ & $\begin{array}{l}2,5 \\
13,16\end{array}$ & $\begin{array}{l}35,19 \\
1,37\end{array}$ & $\begin{array}{l}35,28 \\
34,4 \\
\end{array}$ & $\begin{array}{l}35,23 \\
1,24\end{array}$ & $\begin{array}{l}35,13 \\
8,1 \\
\end{array}$ & & 0 \\
\hline Reliability & $\begin{array}{l}8,28 \\
10,3\end{array}$ & 0 & $\begin{array}{l}10,35 \\
29,39 \\
\end{array}$ & $\begin{array}{l}1,35 \\
29,38 \\
\end{array}$ & $\begin{array}{l}27,17 \\
40 \\
\end{array}$ & $\begin{array}{l}10,24 \\
35,19 \\
\end{array}$ & $\begin{array}{l}10,30 \\
4 \\
\end{array}$ & $\begin{array}{l}21,28 \\
40,3 \\
\end{array}$ & $\begin{array}{l}21,35 \\
11,28 \\
\end{array}$ & 0 & \\
\hline
\end{tabular}

Figure 6 shows the distribution of the dominant inventive principles generated by the contradiction matrix, while figure 7 present the distribution of all the inventive principles generated by the contradiction matrix.

From these graphs the inventive principles that should studied carefully are:

35: Parameter changes.

10: Preliminary action.

28: Mechanics substitution.

15: Dynamics.

3: Local quality

2: Taking out 


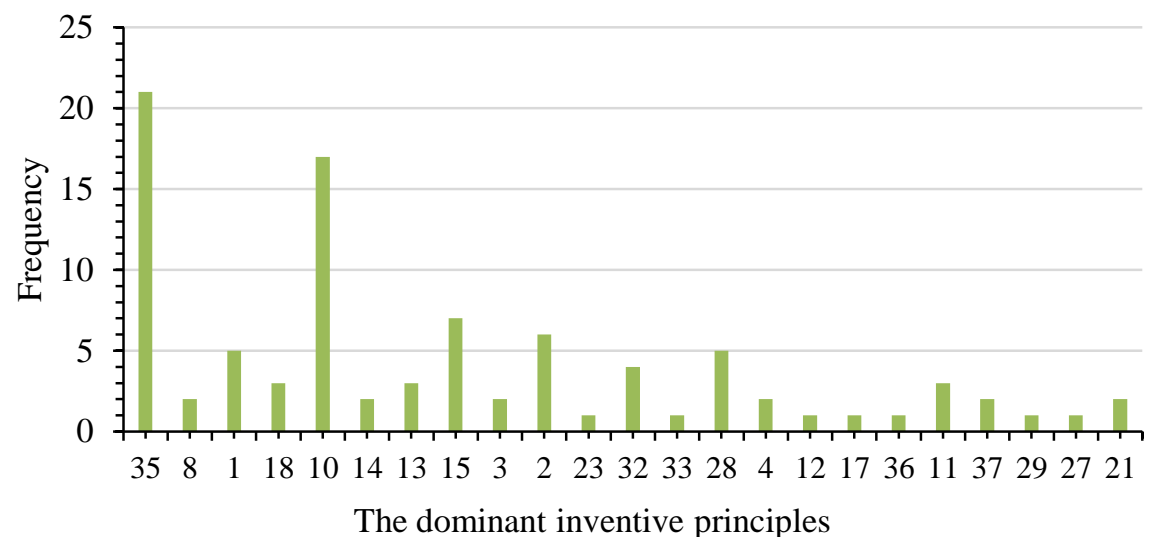

Fig. 6. The distribution of the dominant inventive principle.

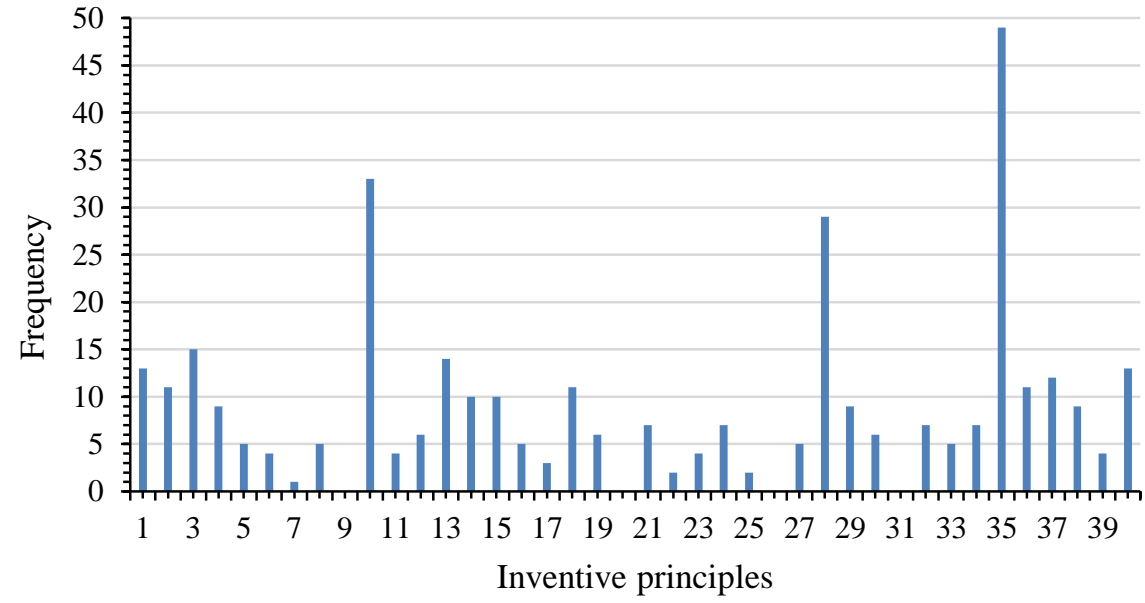

Fig. 7. The distribution of all inventive principles.

\section{Concepts generation}

The application of these Inventive principles allow us to find the old LCM processes as well as to propose the new LCM mold. Details of the new LCM mold components and the main stage of the manufacturing cycle will be presented at the conference. The use of the inventive principle: 35 "parameter changes" with the recommendation "change the degree of flexibility" permits to find the concept depicted in the figure 9. 
In the CRTM process, the mold cover is always made of a single rigid part. Thereby the CRTM needs a high force to displace the moveable upper mold and to better compress the preform, this lead to increase cost equipment and to deform mold walls which influence the part quality. However, these limitations can be minimized by using an upper mold made of several pieces that can be articulated separately. This variant called ACRTM (“articulated compression resin transfer molding”) [24].

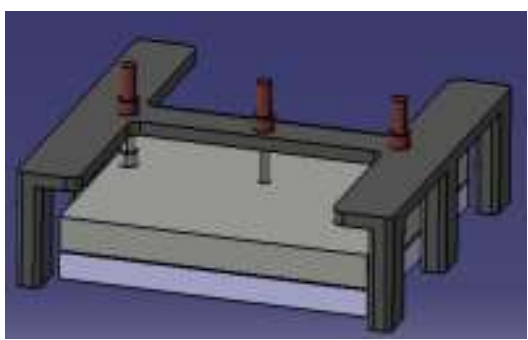

Fig. 8. The CRTM mold.

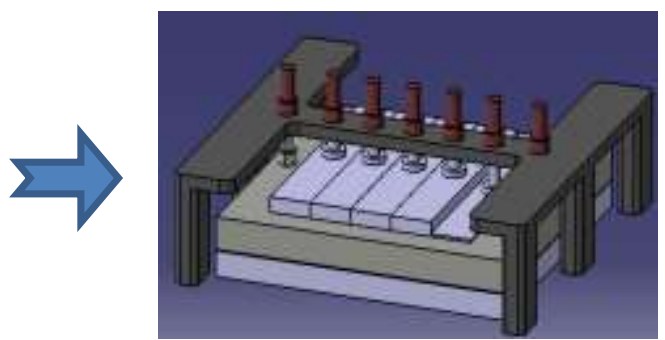

Fig. 9. The ACRTM mold.

The use of the inventive principle: 28 "Mechanics substitution" with recommendation "Use electric, magnetic and electromagnetic fields to interact with the object" allows us to propose a new variant of VARTM process called "Relaxation-compression resin transfer molding under magnetic field" as illustrated in the figure 10. In this process, we only use a single rigid side mold like as in the VARTM processes, that contains the fiber preform, and it covers by a flexible magnetic membrane, or by using a vacuum bag including a ferromagnetic sheet, gathered together by an effective glue. The magnetic field is controlled by the current intensity or by the separated gap between the coil and ferromagnetic membrane, so as to apply a magnetic force on the membrane and as a result, move it up to relax the preform or down in order to compress the fiber reinforcement. Which leads to speed up the impregnation velocity and increase the fiber volume fraction.

Displacement system Ferromagnetic sheet

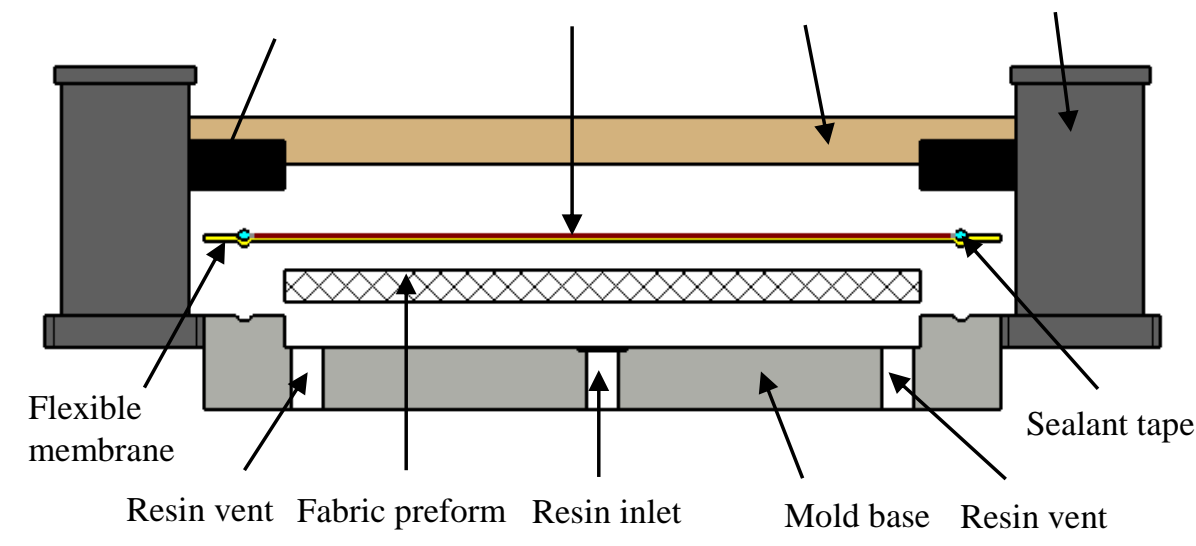

Fig.10. Relaxation-compression resin transfer molding under magnetic field mold components 
The use of the inventive principle: 15 "Dynamics" with recommendation "divide an object into parts capable to move relative to each other" permits to generate the process proposed by Chang, called "PCM: Progressive compression method" [25], as illustrated in the figure 12. This process belongs to the vacuum infusion processes (VIPs), as well as it's an evolution of the flexible injection process [26]. The PCM reduces the filling time compared to the vacuum infusion processes.

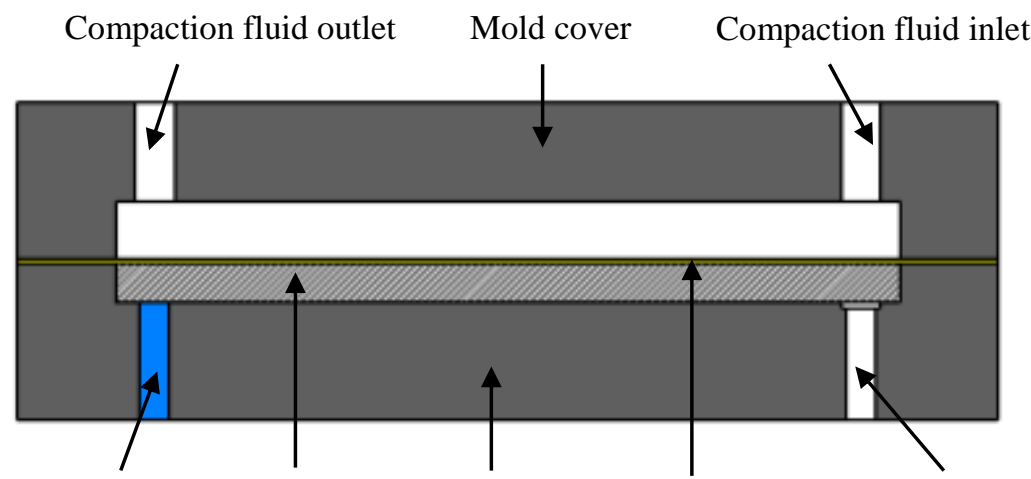

Resin outlet Fabric preform Mold base Flexible membrane Resin inlet

Fig.11. Flexible injection mold components

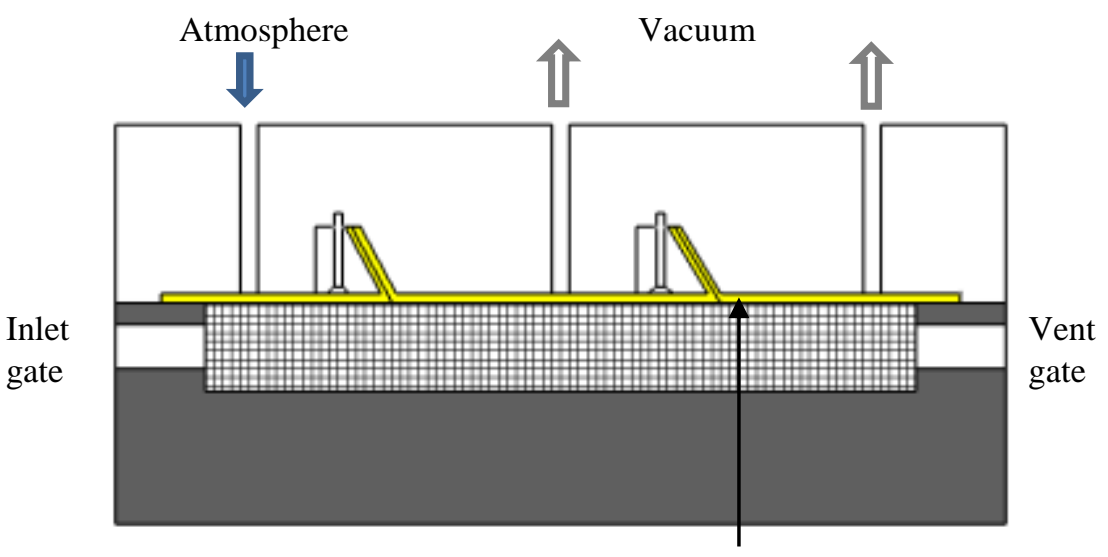

Flexible membrane

Fig.12. The PCM mold [26]

\section{Conclusion and outlook}

This paper emphasizes the capacity of TRIZ theory to solve the conflict links existed between the aeronautic and automotive requirements. Moreover to propose the new 
solutions capable to maintain simultaneously the cadence of the automobile and the quality of aerospace industries.

To evaluate the efficiency of each solution and its capacity to satisfy the aeronautic and automotive conditions, we suggest to use the analytical and numerical approaches before fabricate the prototypes and going into the experimental approach.

\section{References}

1. Lopatnikov, S.: A closed form solution to describe infusion of resin under vacuum in deformable fibrous porous media, Modelling Simul. Mater. Sci. Eng. 12, S191-S204 (2004).

2. Sozer, EM.: Manufacturing techniques for polymer matrix composites (PMCs), Woodhead Publishing Limited, Cambridge, 2012.

3. Potter, K.: Resin transfer moulding, Chapman \& Hall, London, 1997.

4. Marsh, G.: Composites on the road to the big time? Reinforced Plastics 47(2):33-36 (2003).

5. Wang, J.: Use of medial axis to find optimal channel designs to reduce mold filling time in resin transfer molding, Compos A Appl Sci Manuf 95(Supplement C):161-72 (2017).

6. Song, H.: Study on high-speed RTM to reduce the impregnation time of carbon/epoxy composites, Composite Structures 119, 50-58 (2015).

7. Seemann, WH.: Plastic transfer molding techniques for the production of fiber reinforced plastic structures, US Patent No. 4902,215, 1990.

8. Alms, JB., Advani, SG.: Simulation and experimental validation of flow flooding chamber method of resin delivery in liquid composite molding, Compos Part A Appl Sci Manuf 38, 2131-41(2007).

9. Alms, JB., Advani, SG., Glancey, JL.: Liquid composite molding control methodologies using vacuum induced preform relaxation, Compos Part A Appl Sci Manuf 42,5765(2011).

10. Chang, CY.: Experimental analysis of mold filling in vacuum assisted compression resin transfer molding, J. Reinf Plast Comp 31,1630-1637(2012).

11. Mansoor, M., Mariun, N., Toudeshki, A., Wahab, N.I.A., Mian, A.U., Hojabri, M.: Innovating problem solving in power quality devices: a survey based on dynamic voltage restorer case. Renew Sustain Energy Rev. 70, 1207-1216 (2017).

12. Abramov, O., Kogan, S., Mitnik-Gankin, L., Sigalovsky, I., Smirnov, A.: TRIZ-based approach for accelerating innovation in chemical engineering. Chemical Engineering Research and Design 103, 25-31(2015).

13. Azammi, AMN., Saquan, SM., Ishak, MR., Sultan, MTH.: Conceptual design of automobile engine rubber mounting composite using TRIZ-Morphological chart-analytic network process technique. Defence Technology, vol. 14, no. 4, pp. 268-277 (2018).

14. Cempel, C.: Application of TRIZ approach to machine vibration condition monitoring problems. Mechanical Systems and Signal Processing 41, 328-334 (2013).

15. Zhang, J., Shang, J.: Research on developing environmental protection industry based on TRIZ theory. Procedia Environmental Sciences 2, 1326-1334 (2010).

16. Zouaoua-ragab, D.: Lois d'evolution de TRiZ pour la conception des futures generations des produits : Proposition d'un modele. PhD Thesis Arts and Crafts ParisTech, 2012.

17. Ilevbare, M., Probert, D., Phaal, R.: A review of TRIZ, and its benefits and challenges in practice; Technovation 33, pp. 30-37 (2013). 
18. Fey, V.: Dilemma of a Radical Innovation - A New View on the Law of Transition to a Micro-Level. TRIZ journal (1999).

19. Domb, E., Miller, JA.: Applying the Law of the Completeness of a Technological System to Formulate a Problem. TRIZ journal (2007).

20. Belu, N., Rachieru, N., Militaru, E., Anghel, D.: Application of FMEA method in product development stage. Academic Journal of Manufacturing Engineering, 10(3), 12-19 (2012).

21. Ko, YT.: Modeling a hybrid-compact design matrix for new product innovation. Computers and Industrial Engineering, 107, 345-359 (2017).

22. Zhang, P., Essaid, A., Zanni-Merk, C., Cavallucci, D., Ghabri, S.: Experience capitalization to support decision making in inventive problem solving. Computers in Industry Vol. 101, 25-40 (2018).

23. Pokhrel, C., Cruz, C., Ramirez, Y., Kraslawski, A.: Adaptation of TRIZ contradiction matrix for solving problems in process engineering. Chemical Engineering Research and Design. Vol.103, 3-10 (2015).

24. Achim, V., Soukane, S., Gauvin, R., Trochu, F.: Simulation of articulated compression resin transfer molding. The 8th International Conference on Flow Processes in Composite Materials (FPCM8) Douai, FRANCE - 11 - 13 July 2006.

25. Chang, CY.: Numerical study on filling process in progressive compression method. Adv Compos Mater. Epub ahead of print 24 November 2017. DOI: 10.1080/ 09243046.2017.1405598

26. Ruiz. E., Briones. LR., Allard. É., Trochu. F.: Flexible injection: a novel LCM technology for low cost manufacturing of high performance composites. Part I: experimental investigation. Proceedings FPCM9, 34 (2008). 